Article

\title{
Competence Development and Employability Expectations: A Gender Perspective of Mobility Programmes in Higher Education
}

\author{
Francisca Rosa Álamo-Vera *Did, Lidia Hernández-López, José Luis Ballesteros-Rodríguez $\mathbb{D}$ and \\ Petra De Saá-Pérez \\ Department of Economics and Business Administration, Faculty of Economía, University of Las Palmas de \\ Gran Canaria, Empresa y Turismo, E-35017 Las Palmas de Gran Canaria, Las Palmas, Spain; \\ lidiaesther.hernandez@ulpgc.es (L.H.-L.); joseluis.ballesteros@ulpgc.es (J.L.B.-R.); \\ petra.desaaperez@ulpgc.es (P.D.S.-P.) \\ * Correspondence: francisca.alamo@ulpgc.es
}

Received: 24 July 2020; Accepted: 11 September 2020; Published: 14 September 2020

\begin{abstract}
This paper analyses the role of study-abroad programmes in higher education by examining how students' participation can foster competence development and employability expectations. Our research focuses on the acquisition of competences through the international mobility programme Erasmus+ of 191 students of an undergraduate programme in tourism, considering the different perceptions of male and female students. Our results confirm that five out of the six competences which students develop through Erasmus+ mobility have a positive and significant influence on their employability expectations. Our findings also confirm that male and female students have different perceptions concerning the influence on their employability expectations of those competences acquired during their experience studying abroad.
\end{abstract}

Keywords: employability competences; Erasmus+; gender; higher education; mobility programmes; tourism

\section{Introduction}

As Chan et al. (2017) pointed out, the study of generic skill programmes, especially soft skills, in addition to disciplinary knowledge, is a worldwide phenomenon. Marsh and Bishop (2014) also highlighted that competences are a topic of interest and research for educators. In this line, participation in a study abroad programme can contribute to the development of competencies that employers find valuable-such as interpersonal, commercial, innovative/creative or strategic skills, as found by Humburg et al. (2013), making it easier for students to gain and maintain employment (Bótas and Huisman 2013; Bracht et al. 2006; Brandenburg et al. 2015; Bryła, Paweł 2015. The impact of international student mobility on subsequent employment and professional career: A large-scale survey among Polish former Erasmus students 2015; Crossman and Clarke 2010; Engel 2010; Jacobone and Moro 2015; Teichler 1996). The experience of living and studying in a different economic, political and cultural context means that the participants can assimilate "best practices" from other countries and prepare themselves for their professional future. An educational experience abroad allows for improving opportunities in the labour market (Bracht et al. 2006; Brooks and Waters 2011; Kumpikaite and Duoba 2013) because those competencies acquired abroad are a crucial factor that can influence the attainment of a job (Coleman 2011; Crossman and Clarke 2010). In this sense, there are differences between the competences acquired by students who go abroad and those who do not, and there is a positive relationship between the international experience and job opportunities for students (Alfranseder et al. 2012). Compared to non-mobile students, Brandenburg et al. (2015) found out that 
Erasmus students are half as likely to be long-term unemployed; more specifically, these researchers showed that the unemployment rate is substantially lower five years after graduation, and ten years after, Erasmus students are much more likely to hold managerial positions.

Erasmus+ is one of the EU's most successful and iconic programmes. Its backbone has been the support of studying abroad to enhance the skills, employability and intercultural awareness of the participants. Since the launch of Erasmus+ in 1987, more than 9 million people have gone abroad under this programme (European Commission 2018). For the period 2021-2027, its budget has increased to make it possible for up to 12 million people to have an experience abroad (European Commission 2018). In particular, $92 \%$ of the students feel they increase their versatility during the mobility, becoming more resilient, open-minded and curious after being abroad and able to adapt to different situations, and $90 \%$ report feeling more confident and ready to take on new challenges after the international experience.

Furthermore, $87 \%$ of mobile students consider they have become more tolerant of other people's values and behaviours, $87 \%$ can better cooperate with people from different backgrounds and cultures, and $83 \%$ report improved learning skills (European Commission 2017). Thus, for students, participation in Erasmus+ mobility is perceived as having a positive impact on their personal growth and the development of critical transversal skills. Accordingly, international student mobility is often within the curriculum of study programmes. For instance, in Luxembourg, all Bachelor students have a compulsory mobility period of six months. In Austria, some universities have mandatory mobility periods in some of their programmes (e.g., International Business), and in Germany, all higher education institutions have to offer the opportunity of a mobility period for students in all study programmes and this requirement is included in the Common structural guidelines of the Länder (European Commission/EACEA/Eurydice 2018).

Some research works have focused on the assessment of a potential gap between higher education studies and industry requirements for future employees (e.g., Perera et al. 2017). Specifically, in the tourism industry, participation in a study abroad programme can be of high relevance. By fostering the ability to learn in different sociocultural contexts, cultural sensitivity increases among students, and it allows the development of skills necessary to work in the tourism industry, due to its international character. According to the EU statistics, in the EU 28 countries, participation of students in Erasmus+ Programme has experienced a substantial increase (19\%) from 273,000 in 2013/2014 to 325,000 in 2017/2018. Additionally, Turhan (2016) found out that female students are more interested in participating in international mobility programmes, compared to male students. In 2016, there were 396,112 females and 350,211 males, with females representing $53 \%$ and males $47 \%$ of the Erasmus + study abroad population in the field of travel, tourism and leisure (Eurostat 2019). Though there is a rich body of studies of how participation in a study-abroad programme enhances employability competences development (e.g., Brandenburg et al. 2015), less knowledge exists about gender perceptions in international mobility (Cohen et al. 2020; Jöns 2011). A gender perspective is essential as a significant stream of studies have reflected notable differences between males and females in employability competences development (Ain et al. 2019; Gök et al. 2019; Jackson 2016; Won Kim et al. 2020; Nabi and Bagley 1999; O'Leary 2019).

Based on the considerations above, this research attempts to fill a gap in the literature by analysing gender differences regarding how tourism students' participation in a study-abroad programme can foster their employability expectations. The study was carried out at the University of Las Palmas de Gran Canaria, located on the island of Gran Canaria, Canary Islands, Spain. The Canary Islands, by the north east coast of Africa, is the only Spanish Outermost European Region. They cope with the problems of insularity—for instance, being far from the mainland-but the excellent weather conditions allow them to turn the handicaps into sustainable competitiveness, especially in the tourism industry. Canarias is a region with nearly two million inhabitants, and tourism is the most important economic activity, accounting for 35\% of the regional GDP-compared to $15 \%$ for Spain. This is a critical driving force, meaning that the universities in the islands have introduced tourism studies in 
their offer, trying to contribute to the competitiveness of the destination with knowledge resources and qualified workforce.

Specifically, our research focused on the acquisition of competences through the international mobility programme Erasmus+ of 191 outgoing students of the Degree in Tourism of the University of Las Palmas de Gran Canaria (Spain), also considering the different perceptions of male and female students regarding the influence of those competencies on their employability expectations. To this end, the structure of the paper is as follows: the second section includes a conceptual framework for mobility competences development and employability expectations, taking into account gender differences. Section 3 offers the methodological process followed throughout the work, and Section 4 shows the main results obtained in the study. Finally, the last section includes the conclusions and practical implications of the study.

\section{Mobility Competences and Employability Expectations}

Students enrol in higher education as a way to overcome the obstacles that the labour market poses to unemployed or underemployed workers. Thus, higher education institutions are to offer studies that combine theoretical knowledge with practical competences to enhance the employability of graduates and their earnings in the labour market (Menon et al. 2012). As Marsh and Bishop (2014, p. 48) affirmed, "[ ... ] high quality professional practice involves not only requisite knowledge but also a broader set of behaviours related to application and professional conduct."

Concerning the concepts of competence and employability, first, "The concept of competence [ ... ] involves a whole array of knowledge, procedures and attitudes combined, coordinated and integrated, so that the individual has to «know», «know how» and «know how to be» in relation to the professional career" (Tejada-Fernández and Ruiz-Bueno 2016, p. 20). Second, focusing on employability, this concept is a mix of the words "employ" and "ability", and involves the development of competencies which help students to enter and stay in the labour market (García-Blanco and Cárdenas-Sempértegui 2018).

As Crossman and Clarke (2010, in Guardià-Olmos et al. 2018) pointed out, internationalisation helps university students to develop soft competencies, so that they are better prepared for the process of transition into the labour market. In this sense, the Erasmus+ Higher Education Impact Study (European Commission 2019) identifies students' perceived impact of Erasmus+ mobility in five individual factors: (1) intercultural openness (intercultural competences; new international perspectives and dimensions in life; understanding of host countries' culture, society and economy); (2) perceived personality development (attitudes and skills such as tolerance towards different behaviour, decisiveness, ability to assess own strengths and weaknesses); (3) social engagement (social and political engagement; involvement in the local community; critical thinking; commitment to fight discrimination, intolerance); (4) employability skills (skills relevant for employment and careers, including soft-skills, field-specific knowledge); and (5) study progress (progress within studies; competencies relevant for effective learning; experience with innovative teaching methods; motivation to complete studies).

In addition to these individual factors, mobile students also can improve their foreign language and communication skills, as well as gain a broader and more intensive educational and social experience. As Fontes et al. (2013) highlighted, international mobility creates social and cognitive relationships that may facilitate knowledge transmission and network building. However, we should take into account that a language bias could exist, what means that those students with a superior level of a foreign language are more likely to engage in international mobility (Bryła, Paweł 2015. The impact of international student mobility on subsequent employment and professional career: A large-scale survey among Polish former Erasmus students 2015).

Previous work on the participation of hospitality students in study abroad programmes pointed out students' favourable attitude and high satisfaction with the international experience (Behnke et al. 2014). They perceive it as an opportunity that enhances their future career (Bosselman et al. 1989). Furthermore, other studies that highlighted that employers highly value the participation of hospitality 
students in study abroad programmes also support this finding. Those programmes improve employees' global and multicultural experience, greater maturity and confidence, increased willingness to travel and accept foreign assignments, and flexibility in thoughts and actions (Toncar and Cudmore 2000; Trooboff et al. 2008). Thus, based on this literature, we hypothesise the following:

Hypothesis $\mathbf{1}$ (H1). There is a positive relationship between the competences acquired by Erasmus+ students during mobility and their employability expectations.

Moreover, gender is a relevant dimension in competence development (Ain et al. 2019; Almerich et al. 2020; Jackson 2016; Nabi and Bagley 1999; O'Leary 2019) which deserves study. For instance, research by Won Kim et al. (2020) showed how credentials were critical to providing women with better opportunities in the labour market. In other words, women - compared to men-perceive that having credentials helps them to enter and promote in the job market easily, and that is the reason why they enrol in higher education studies, where formal knowledge and non-disciplinary competencies can be acquired.

Additionally, Ain et al. (2019) pointed out gender similarities and differences in competence development in higher education. In their study, they explored male and female graduates' perceptions of research skills developed during their undergraduate degree and used by them in employment for research, investigations and for ongoing learning that kept them current. Their study revealed gender differences in skills development in two of the six research skills investigated: embark and clarify; and analyse and synthesise. Men are less aware of the research skill of embarking and clarifying, namely, embarking on research and clarifying the needs for knowledge, heeding ethical, cultural, and social factors. In contrast, their findings pointed at women's lower awareness of analysing and synthesising, namely, to analyse information and data, and synthesise new knowledge. In addition, research by Jöns (2011) on gender relations in international academic mobility finds participation, experiences and outcomes vary by gender. He found that women are underrepresented as participants in transnational academic mobility.

Furthermore, research by Nabi and Bagley (1999) aimed to examine graduates' perceptions of the quality and importance of skills gained through their undergraduate courses, together with their satisfaction with aspects of their course and university experience. Their work showed significant gender differences in terms of the importance and quality of the skills. Females tended to rate most of the capabilities as more important than males. However, males perceive themselves to be significantly better at communication and problem-solving than females. In contrast, females tended to rate their abilities higher on predominantly personal skills such as team working, time management, planning/organising, and prioritising skills. These findings were confirmed by Jackson (2016), whose work highlighted that women assign greater importance than men to generic skills, which include team-working, communication, critical thinking and self-management. Females - on average- perceived written communication and planning skills to be developed better than males. In contrast, males assigned a higher mean rating for analytic and problem-solving skills and confidence in tackling unfamiliar problems.

O'Leary (2019) found that, for employability-related support, a significant imbalance exists by discipline and consequently by gender; for instance, in female-orientated disciplines-arts, humanities and social sciences-employability-related support remains unseen. Therefore, fewer female graduates may recognise specific capabilities as being management-related, potentially resulting in slower female career advancement and in neglecting female talent (Morgan and Pritchard 2019). These findings are backed up by recent research on female employees in the tourism and hospitality industry. Thus, Segovia-Pérez et al. (2019), in their work on female executives in the Spanish hospitality industry, found that women's poor perceptions of their capabilities were significant barriers to their career development in hospitality organisations. As expressed by Dashper (2019, p. 6), “Women may thus feel like they do not fit in the higher echelons of hospitality organisations, and may attribute this sense 
of being an outsider to their own failings". Moreover, previous studies pointed out that women tend to rate themselves lower than men, and men generally over-report their performance while women tend to underreport it (Paustian-Underdahl et al. 2014; Reuben et al. 2014). Likewise, Stamolampros et al. (2019) noted that, in tourism and hospitality firms, female employees appear to be less satisfied than their male colleagues. Consequently, performance appraisal systems can be unfavourable to women (Festing et al. 2015) as they involve a self-assessment component.

Considering the above arguments, we hypothesise the following:

Hypothesis 2 (H2). The relationship between the competences acquired by Erasmus+ students during mobility and their employability expectations differ according to gender.

\section{Materials and Methods}

Figure 1 shows the steps of the data collection and the analyses carried out to test the hypothesis of our study by using SPSS software.

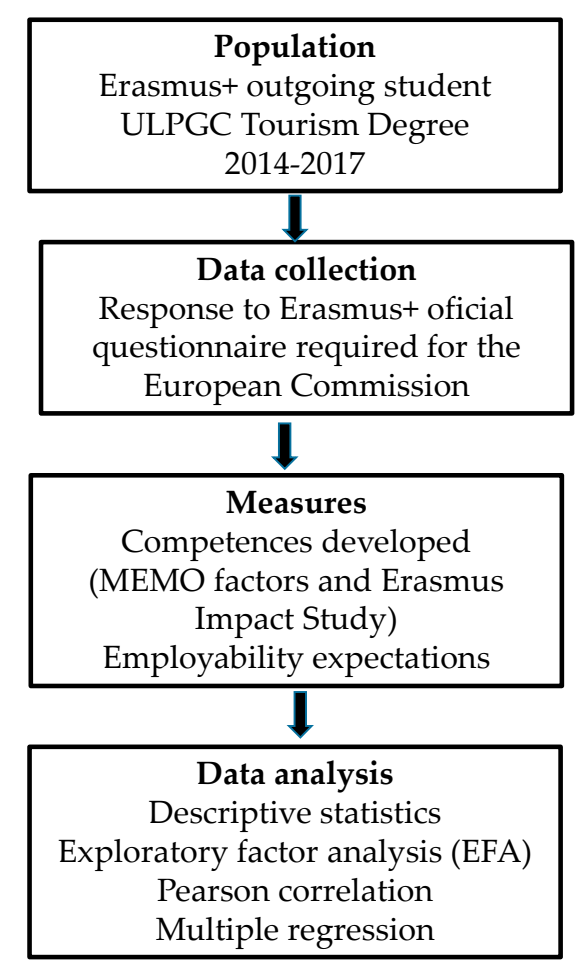

Figure 1. Data gathering and treatment.

\subsection{Data Collection}

To carry out this research, we conducted an empirical study with all the students of the Degree in Tourism of the University of Las Palmas de Gran Canaria who participated in the Erasmus+ programme during the academic years 2014/15, 2015/16 and 2016/17. The International Relations Office of the University kindly supplied us the data available at the moment we requested them.

Data were gathered from the responses to the questionnaire of the European Commission that outgoing students have to fill in when they come back to their home universities. It is an Erasmus+ Programme official questionnaire mandatory for all the students who participate in the international mobility experience. From this questionnaire, we chose nineteen items related to the competencies identified by the Erasmus Impact Study (European Union 2014) and the so-called MEMO factors, which are the competences demanded by the employers according the study by Humburg et al. (2013). 
Those factors are also general competences detailed in the Tourism Degree Report of the University of Las Palmas de Gran Canaria. According to the Bologna agreement, higher education institutions in the European Union have to offer graduate studies focused not only on formal content but also on more informal competencies that have to be assessed. Therefore, students can affirm—or not—if they perceive the acquisition of competencies such as teamwork, language fluency, problem-solving, and so on during their Erasmus+ experience. Moreover, we also used out of the questionnaire three items regarding students' employability expectations after the Erasmus+ experience (see Table 1).

Table 1. Questionnaire items related to the competencies developed.

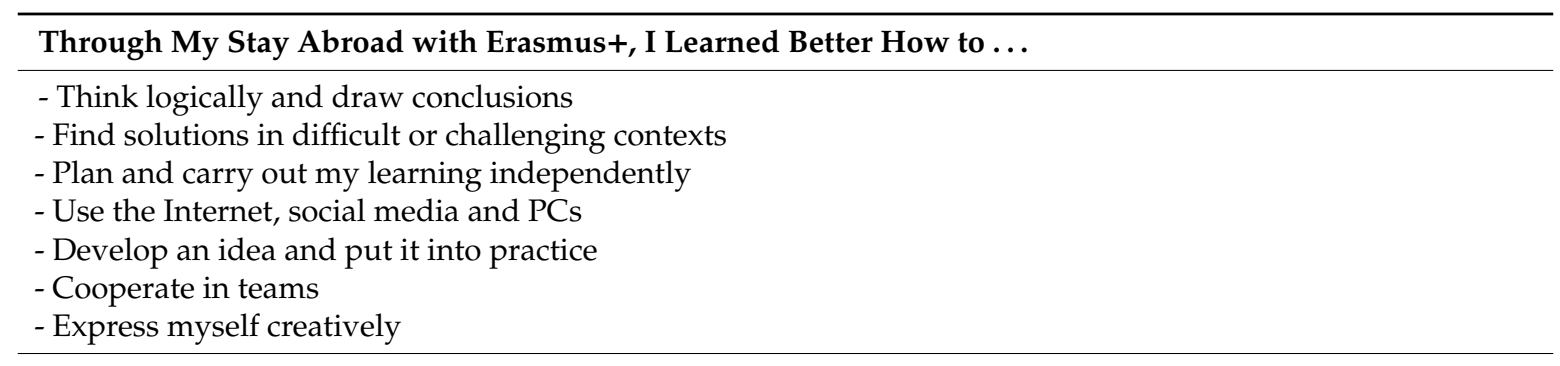

After having taken part in this mobility activity, I...

- Am more confident and convinced of my abilities

- Know better my strengths and weaknesses

- Am able to adapt to and act in new situations

- Am able to think and analyse information critically

- Am more tolerant of other person's values and behaviour

- Am more open-minded and curious about new challenges

- Intend to participate more actively in the social and political life of my community

- Have a higher capacity to make decisions

- Am able to cooperate better with people of different origins and cultures

- Have more interest in European issues

- Feel more European

- Am more aware of social and political concepts such as democracy, justice, equality, citizenship, and civil rights

Thanks to my stay abroad with Erasmus+, I...

- Think the chances of finding a new or better job have increased

- Have clearer my professional objectives and aspirations

- Have a greater capacity to be assigned tasks with high responsibility

As Table 2 shows, most of the respondents chose Germany (50.3\%) and the United Kingdom (23\%) as the destination for their Erasmus+ experience. Concerning gender, the number of women is quite high compared to men ( $67 \%$ women and $33 \%$ men).

Table 2. Respondent profile.

\begin{tabular}{ccc}
\hline Country of the Host University & Number of Students & \% of Students \\
\hline Germany & 96 & $50.3 \%$ \\
United Kingdom & 44 & $23.0 \%$ \\
Western EU countries (Belgium, Italy, France, & 26 & $13.6 \%$ \\
The Netherlands, and Portugal) & & \\
Eastern EU countries (Poland, Croatia, Slovakia, Latvia, & 25 & $13.1 \%$ \\
Lithuania, and the Czech Republic) & 191 & $100.0 \%$ \\
Total & Number of Students & $\%$ of Students \\
\hline Gender & 63 & $33.0 \%$ \\
Male & 128 & $67.0 \%$ \\
Female & 191 & $100.0 \%$ \\
\hline Total & &
\end{tabular}




\subsection{Data Treatment}

To identify those competences developed by the students, two exploratory factor analyses (EFA) with varimax rotation were carried out - the first one with the items of the questionnaire concerning the competences developed in the Erasmus+ mobility experience, and the second one on the aspects related to employability expectations. This analysis let us summarize the information contained in the questionnaire, keeping a high percentage of variance explained. Before applying the EFA, the statistical suitability was analyzed using Bartlett's sphericity test and the Kaiser-Meyer-Olkin index. Bartlett's test of sphericity yielded a chi-square value of 0.45 with a $p$ value of 0.000 , meaning the null hypothesis of non-correlation between variables was rejected. These aspects are usually checked by applying the KMO test of sampling adequacy, which must yield a value between 0 and 1 . Low measures (less than 0.5) show that factor analysis is unadvisable, given that the correlations between pairs of variables cannot be explained by other variables. A value close to 1 indicates that the data are fully adequate for a model of factor analysisis obtained. The results of our analysis show KMO values of 0.87 and 0.66 . Bartlett's test of sphericity measures the multivariate normality of the distribution and by checking the null hypothesis that the original correlation matrix is an identity matrix. Thus, if the significance value is less than 0.05 , that means the data are suitable for further analysis. Finally, the reliability analysis, using Cronbach's alpha, showed that the items used in the constructs are reliable and consistent, because all the values for Cronbach alpha coefficientes were greater than 0.60 (Nunnally and Bernstein 1994).

To test the hypothesis, we carried out two parametric analysis: Pearson correlations and multiple regression analysis. The suitability of data for parametric statistical procedures was ensured before carrying out the analysis (see Table 3). Histograms and pp-plot were used to ensure normality and linearity. Durbin-Watson values between the critical ones $(1.5<\mathrm{d}>2.5)$ allow us to assume that there is not a first order linear auto-correlation. Values of the variance inflation factor (VIF) were less than 4 for all the regression models, indicating that there were not any multicollinearity problems.

Table 3. Data suitability for parametric statistical procedures.

\begin{tabular}{lll}
\hline \multicolumn{1}{c}{ Assumptions } & \multicolumn{1}{c}{ Threshold Point } & \multicolumn{1}{c}{ Model Values } \\
\hline \multirow{2}{*}{ Durbin Watson } & & General model: 1.73 \\
& $1.5-2.5$ & Male model: 1.85 \\
& & Female model: 1.87 \\
\hline Variance Inflation Factor (VIF) & VIF $<4$ & Maximum \\
& & General model: 2.51 \\
& & Male model: 1.92 \\
Normality & Female model: 3.10 \\
Linearity & & Histogram \\
\hline
\end{tabular}

\section{Results}

From the results of the EFA for the nineteen items regarding the competencies developed through the Erasmus+ Programme by tourism students, six factors are obtained that explain $67.76 \%$ of the variance (see Table 4). These factors received the following names: socio-culturally open-minded, self-confidence, European social consciousness, problem-solving ability, independent workability, and interpersonal skills. All the dimensions have good factor loads, and Cronbach's alphas confirm the suitability of the analysis since their values are above the minimum recommended thresholds. 
Table 4. Results of the exploratory factor analysis for the competences developed during the Erasmus+.

\begin{tabular}{|c|c|c|}
\hline Competences & Factor Load & Cronbach Alpha \\
\hline \multicolumn{3}{|l|}{ F1. Socio-culturally open-minded } \\
\hline Being more open-minded and curious about new challenges & 0.773 & \multirow[b]{2}{*}{0.726} \\
\hline $\begin{array}{l}\text { Being able to cooperate better with people of different origins } \\
\text { and cultures }\end{array}$ & 0.711 & \\
\hline \multicolumn{3}{|l|}{ F2. Self-confidence } \\
\hline Knowing better my strengths and weaknesses & 0.802 & \multirow{4}{*}{0.830} \\
\hline Being more confident and convinced of my abilities & 0.709 & \\
\hline Being able to adapt to and act in new situations & 0.592 & \\
\hline Being able to think and analyse information critically & 0.557 & \\
\hline \multicolumn{3}{|l|}{ F3. European social consciousness } \\
\hline Feeling more European & 0.816 & \multirow{4}{*}{0.730} \\
\hline $\begin{array}{l}\text { Being more aware of social and political concepts such as democracy, } \\
\text { justice, equality, citizenship, and civil rights }\end{array}$ & 0.766 & \\
\hline Having more interest in European issues & 0.572 & \\
\hline $\begin{array}{l}\text { Intending to participate more actively in the social and political life of } \\
\text { my community }\end{array}$ & 0.533 & \\
\hline \multicolumn{3}{|l|}{ F4. Problem-solving ability } \\
\hline Thinking logically and draw conclusions & 0.803 & \multirow{3}{*}{0.712} \\
\hline Having a higher capacity to make decisions & 0.583 & \\
\hline Finding solutions in difficult or challenging contexts & 0.560 & \\
\hline \multicolumn{3}{|l|}{ F5. Independent workability } \\
\hline Using the Internet, social media and PCs & 0.787 & \multirow{3}{*}{0.684} \\
\hline Developing an idea and put it into practice & 0.703 & \\
\hline Planning and carry out my learning independently & 0.608 & \\
\hline \multicolumn{3}{|l|}{ F6. Interpersonal skills } \\
\hline Cooperating in teams & 0.796 & \multirow{6}{*}{0.688} \\
\hline Expressing myself creatively & 0.784 & \\
\hline Percentage of variance explained: 67.76 & & \\
\hline KMO Index: 0.875 & & \\
\hline Bartlett's sphericity test: 1455.448 & & \\
\hline Significance: 0.000 & & \\
\hline
\end{tabular}

The EFA for the items related to employability expectations appears in Table 5. The results show one factor that explains $64.08 \%$ of the variance, with a Cronbach's alpha of the scale that exceeds 0.70 , which indicates that the extracted factor is adequate.

Table 5. Exploratory factor analysis results for employability expectations.

\begin{tabular}{lll}
\multicolumn{1}{c}{ Competences } & Factor Load & Cronbach Alpha \\
\hline Thinking the chances of finding a new or better job have increased & 0.827 & \\
Having a greater capacity to be assigned tasks with high responsibility & 0.818 & 0.718 \\
Having clearer my professional objectives and aspirations & 0.754 & \\
Percentage of variance explained: 64.08 & \\
KMO Index: 0.668 & \\
Bartlett's sphericity test: 113.375 & \\
Significance: 0.000 & \\
\hline
\end{tabular}

Table 6 shows the correlation between students' perception of employability expectations after the mobility and the competences acquired through the Erasmus+ mobility programmes. The results show that there is a positive and significant relationship between five of the competences acquired and employability expectations: socio-culturally open-minded $(\mathrm{r}=0.193, p<0.01)$, self-confidence $(\mathrm{r}=0.361$, $p<0.001)$, European social consciousness $(\mathrm{r}=0.213, p<0.01)$, problem-solving ability $(\mathrm{r}=0.301$, $p<0.001)$, and independent workability $(\mathrm{r}=0.228, p<0.01)$. Thus, only the factor "interpersonal 
skills" does not have a significant correlation. Regarding the control variables, neither gender nor the country of the stay shows a significant relation with employability expectations.

Table 6. Correlation between competences and employability expectations.

\begin{tabular}{cc}
\hline Variables & Employability \\
\hline Gender & 0.046 \\
Germany & -0.094 \\
UK & 0.129 \\
Western EU countries & 0.059 \\
Eastern EU countries & -0.083 \\
F1. Socio-culturally open-minded & $0.193^{* *}$ \\
F2. Self-confidence & $0.361^{* * *}$ \\
F3. European social consciousness & $0.213^{* *}$ \\
F4. Problem-solving ability & $0.301^{* * *}$ \\
F5. Independent work ability & $0.228^{* *}$ \\
F6. Interpersonal skills & 0.086 \\
\hline
\end{tabular}

*** $p<0.001 ; * * p<0.01$.

Table 7 summarises the primary outcomes of the regression analyses. Regarding the effect of the explanatory variables, our results show that all the competencies that students develop through the mobility programme-except for "interpersonal skills"-have a positive and significant influence on their employability expectations: socio-culturally open-minded $(\beta=0.205 ; p<0.01)$, self-confidence ( $\beta=0.354 ; p<0.001)$, European social consciousness $(\beta=0.224 ; p<0.001)$, problem-solving ability $(\beta=0.293 ; p<0.001)$, and independent workability $(\beta=0.222 ; p<0.001)$. Concerning the host country, our findings also reveal that those students who went to Western EU and the United Kingdom, compared to Eastern EU, have higher employability expectations. Therefore, Hypothesis 1, which established a positive relationship between the competences acquired by Erasmus+ students and their employability expectations can be accepted.

Table 7. Regression model: employability expectations.

\begin{tabular}{ccc}
\hline Competences & \multicolumn{2}{c}{ Employability } \\
\cline { 2 - 3 } & Beta & $\mathbf{t}$ \\
\hline (Constant) & -0.287 & -1.658 \\
Gender & 0.027 & 0.450 \\
Germany & 0.106 & 1.148 \\
UK & $0.148^{*}$ & 2.049 \\
Western EU countries & $0.162^{*}$ & 2.070 \\
F1. Socio-culturally open-minded & $0.205^{* *}$ & 3.479 \\
F2. Self-confidence & $0.354^{* * *}$ & 6.001 \\
F3. European social consciousness & $0.224^{* * *}$ & 3.754 \\
F4. Problem-solving ability & $0.293^{* * *}$ & 4.957 \\
F5. Independent workability & $0.222^{* * *}$ & 3.673 \\
F6. Interpersonal skills & 0.083 & 1.400 \\
$\mathrm{R}^{2}$ & \multicolumn{2}{c}{0.385} \\
Adjusted $\mathrm{R}^{2}$ & \multicolumn{2}{c}{0.351} \\
$\mathrm{~F}$ & \multicolumn{2}{c}{$11.268^{* * *}$} \\
\hline$* * * p<0.001 ; * * p<0.01:{ }^{*} p<0.05$. Eliminated country: Eastern EU.
\end{tabular}

To test Hypothesis 2, we carried out two regression models, one for male and other for female Erasmus+ tourism students (see Table 8). The MALE model was significant $(\mathrm{F}=5.428, p<0.001$ ), and the results show that for male students, their employability expectations are positive and significantly 
influenced by three competencies: self-confidence $(\beta=0.392 ; p<0.001)$, European social consciousness $(\beta=0.218 ; p<0.05)$, and interpersonal skills $(\beta=0.254 ; p<0.05)$. Nevertheless, socio-culturally open-minded $(\beta=0.165 ; p>0.05)$, problem-solving ability $(\beta=0.139 ; p>0.05)$, and independent workability $(\beta=0.203 ; p>0.05)$ are not significant. Concerning the host country, our findings also reveal that this variable did not have a significant influence on male students' employability expectations.

Table 8. Regression models: gender perceptions about employability expectations.

\begin{tabular}{|c|c|c|c|c|}
\hline \multirow{3}{*}{ Competences } & \multicolumn{4}{|c|}{ Employability } \\
\hline & \multicolumn{2}{|c|}{ MALE } & \multicolumn{2}{|c|}{ FEMALE } \\
\hline & Beta & $\mathbf{t}$ & Beta & $\mathbf{t}$ \\
\hline (Constant) & & -0.271 & & -1.945 \\
\hline Germany & -0.49 & -0.359 & 0.209 & 1.662 \\
\hline UK & 0.165 & 1.217 & 0.190 & 1.650 \\
\hline Western EU countries & 0.080 & 0.650 & $0.243 *$ & 2.391 \\
\hline F1. Socio-culturally open-minded & 0.165 & 1.512 & $0.256^{* *}$ & 3.512 \\
\hline F2. Self-confidence & $0.392^{* * *}$ & 3.733 & $0.321^{* * *}$ & 4.441 \\
\hline F3. European social consciousness & $0.218 *$ & 2.154 & $0.195^{* *}$ & 2.657 \\
\hline F4. Problem-solving ability & 0.139 & 1.323 & $0.351^{* * *}$ & 4.887 \\
\hline F5. Independent work ability & 0.203 & 1.893 & $0.231 * *$ & 3.130 \\
\hline F6. Interpersonal skills & 0.254 * & 2.380 & 0.002 & 0.031 \\
\hline $\mathrm{R}^{2}$ & \multicolumn{2}{|c|}{0.480} & \multicolumn{2}{|c|}{0.399} \\
\hline Adjusted $\mathrm{R}^{2}$ & \multicolumn{2}{|c|}{0.391} & \multicolumn{2}{|c|}{0.353} \\
\hline $\mathrm{F}$ & \multicolumn{2}{|c|}{$5.428 * * *$} & \multicolumn{2}{|c|}{$8.709^{* * *}$} \\
\hline
\end{tabular}

${ }^{* * *} p<0.001 ;{ }^{* *} p<0.01:{ }^{*} p<0.05$. Eliminated country: Eastern EU.

The FEMALE model was also significant $(\mathrm{F}=8.709, p<0.001)$ and reveals that in the case of female students, five of the six competencies analysed have a positive and significant influence in their employability expectations: socio-culturally open-minded $(\beta=0.256 ; p<0.01)$, self-confidence ( $\beta=0.321 ; p<0.001)$, European social consciousness $(\beta=0.195 ; p<0.01)$, problem-solving ability $(\beta=0.351 ; p<0.001)$, and independent workability $(\beta=0.231 ; p<0.01)$. However, their interpersonal skills do not influence their employability expectations $(\beta=0.002 ; p>0.05)$. Moreover, our findings also show that those female students who went to Western EU countries, compared to Eastern EU countries, have higher employability expectations.

Therefore, according to our findings, we can conclude that male and female Erasmus+ tourism students have different perceptions, concerning the influence on their employability expectations, of those competences acquired during their experience studying abroad. Hence, Hypothesis 2 can also be accepted.

\section{Conclusions}

Our study contributes to the growing stream of literature which tackles the role of study-abroad programmes in education with the perspectives of employability competence development (Behnke et al. 2014; Brandenburg et al. 2015; Bryła, Paweł 2015. The impact of international student mobility on subsequent employment and professional career: A large-scale survey among Polish former Erasmus students 2015). The work analyses the experience of international mobility through the Erasmus+ Programme and its relationship with the employability expectations of tourism students, considering gender differences. The results of our analysis reveal that the acquisition of competencies such as socio-culturally open-minded, self-confidence, European social consciousness, problem-solving ability and independent workability, developed in the Erasmus+ mobility programme, are essential in their job expectations for the future. 
When considering to what extent the perceived outcomes of participation in international mobility vary by gender, our results also show that only two mobility competences-self-confidence and European social consciousness-have a positive and significant influence on employability expectations both for men and women. Our findings also show that, between male and female students, there do exist significant differences concerning the competencies acquired during the Erasmus+ mobility programme with a positive influence on their employability expectations, in line with the findings of previous studies on gender differences in competence development (Ain et al. 2019; Jackson 2016; Jöns 2011; Nabi and Bagley 1999; O'Leary 2019). Thus, for women—compared to men-socio-culturally open-minded, problem-solving ability and independent work ability competencies developed through mobility are relevant for employment. In contrast, only male students consider that interpersonal skills acquired during the mobility programme are essential to get a job in the future. Finally, only female students think that the host country is a relevant factor in employability expectations, as they perceive a positive effect of a mobility programme in Western EU countries compared to Eastern EU countries.

Therefore, our results make two outstanding contributions. First, they reveal that, in the specific context of tourism higher education, an open-minded sociocultural student, able to adapt to new situations and to work with people from different backgrounds, can better perform their work in multicultural work environments. In addition, mobility experiences make students more aware of European social consciousness. They also increase their competences regarding the ability to solve problems and work independently, a critical aspect of the dynamic and changing environment in which the tourism industry develops. Finally, tourism students have also acquired competencies related to greater self-confidence. Therefore, the Erasmus+ programme can become a valuable tool to improve the level of students' skills, thus helping to reduce the gap between the academic and the professional world, especially in the tourism industry, due to the international character of this activity (Trooboff et al. 2008).

Second, for female students, five out of the six competencies developed through mobility are essential to get a job in the future. Therefore, our research finds out that Erasmus+ is employability support for female graduates, who recognise specific capabilities as management-related in line with the work by O'Leary (2019) regarding the need to enhance female graduates' employability self-perception. Thus, our findings reveal that female tourism students who participate in mobility programmes have better perceptions of their capabilities, which can help to overcome the significant barriers to their career development in hospitality organisations (Segovia-Pérez et al. 2019). Thus, this research contributes to producing gender-aware knowledge to better understand gender inequalities in management positions (Carvalho et al. 2019; Morgan and Pritchard 2019), in an industry which remains overly gender-segregated (Fairclough 2018; Muñoz-Bullón 2009; Santero-Sanchez et al. 2015; Santos and Varejão 2007), and with a prevalence of men in top-level management positions (Baum 2015; Baum et al. 2016). Therefore, the integration of international mobility into tourism education is a policy that universities can adopt to remove the "glass ceiling" that hampers female tourism graduates in their professional career, namely, lower employability self-perceptions among females (Morgan and Pritchard 2019; Segovia-Pérez et al. 2019). Through this educational activity, it is possible to bring about a social change by reducing gender inequalities (Cabello Martínez and Martín 2017) in industries where there is significant horizontal and vertical segregation, such as tourism (Ferreira-Freire-Guimarães and Silva 2016).

The third contribution of this paper is to highlight the relevance of integrating international mobility into higher education, particularly in tourism education, which requires the use of alternative teaching methods to prepare a skilled and qualified workforce to respond to the intense development of the tourism industry (Mei 2019). This practice is implemented through the so-called "mobility windows" which are already used by some European higher education institutions.

Finally, this study has some limitations. The acquisition of mobility competencies with potential influence on employability expectations were measured through students' self-reporting. Therefore, future research could also include employability indicators. Because the study focuses on the responses 
from one European university, the generalisation of results should be made with caution. Future research should expand the key respondents to include outgoing students from various European universities, to enrich the information and obtain cross-cultural results. Our research focuses on tourism education context, so additional research could help investigate whether the mobility competencies found out are also relevant for employability expectations in other fields of the European Higher Education Area, such as engineering, law, or medical science. Moreover, gender differences in the mentioned new contexts of study could be analysed.

Author Contributions: Conceptualization, F.R.Á.-V. and L.H.-L.; methodology, P.D.S.-P.; validation, J.L.B.-R.; formal analysis, F.R.Á.-V. and P.D.S.-P.; investigation, F.R.Á.-V. and L.H.-L.; data curation, L.H.-L. and P.D.S.-P.; writing—original draft preparation, F.R.Á.-V. and L.H.-L.; writing—review and editing, F.R.Á.-V., P.D.S.-P. and J.L.B.-R.; supervision, P.D.S.-P.; project administration, P.D.S.-P.; funding acquisition, F.R.Á.-V. and P.D.S.-P. All authors have read and agreed to the published version of the manuscript.

Funding: This research work has been developed under the framework of the Research Project CEI2018-13 funded by the Consejería de Economía, Industria, Comercio y Conocimiento of the Government of the Canary Islands, and the Research Project ULPGC2018-01 funded by the University of Las Palmas de Gran Canaria.

Conflicts of Interest: The authors declare no conflict of interest.

\section{References}

Ain, Chean Toing, Fizza Sabir, and John Willison. 2019. Research skills that men and women developed at university and then used in workplaces. Studies in Higher Education 44: 2346-58. [CrossRef]

Alfranseder, Emanuel, Jesús Escrivá, Julia Fellinger, Aimee Haley, Asror Nigmonov, and Marge Taivere. 2012. Exchange, Employment and Added Value. Brussels: Erasmus Student Network AISBL.

Almerich, Gonzalo, Jesús Suárez-Rodríguez, Isabel Díaz-García, and Natividad Orellana. 2020. Estructura de las competencias del siglo XXI en alumnado del ámbito educativo. Factores personales influyentes. Educación XX1 23: 45-74. [CrossRef]

Baum, Tom. 2015. Human resources in tourism: Still waiting for change?-A 2015 reprise. Tourism Management 50: 204-12. [CrossRef]

Baum, Tom, Anna Kralj, Richard N. Robinson, and David J. Solnet. 2016. Tourism workforce research: A review, taxonomy and agenda. Annals of Tourism Research 60: 1-22. [CrossRef]

Behnke, Carl, Soobin Seo, and Kay Miller. 2014. Enhancing the study abroad experience: A longitudinal analysis of hospitality-oriented, study abroad programme evaluations. Tourism Management 42: 271-81. [CrossRef]

Bosselman, Robert H., Jeffrey A. Fernsten, Peter B. Manning, and Martin Kisseleff. 1989. The international study abroad experience and its effects on hospitality students. Journal of Hospitality $\mathcal{E}$ Tourism Research 13: 287-97.

Bótas, Paulo Charles Pimentel, and Jeroen Huisman. 2013. A Bourdieusian analysis of the participation of Polish students in the ERASMUS programme: Cultural and social capital perspectives. Higher Education 66: 741-54. [CrossRef]

Bracht, Oliver, Constanze Engel, Kerstin Janson, Albert Over, Harald Schomburg, and Ulrich Teichler. 2006. The Professional Value of Erasmus Mobility. Final Report Presented to the European Commission-DG Education and Culture. Kassel: INCHER, University of Kassel.

Brandenburg, Uwe, Obdulia Taboadela, and Michaela Vancea. 2015. Mobility matters: The ERASMUS impact study. International Higher Education 82: 5-7. [CrossRef]

Brooks, Rachel, and Johanna Waters. 2011. Student Mobilities, Migration and the Internationalisation of Higher Education. Hampshire: Palgrave Macmillan UK.

2015. Bryła, Paweł 2015. The impact of international student mobility on subsequent employment and professional career: A large-scale survey among Polish former Erasmus students. Procedia-Social and Behavioral Sciences 176: 633-41. [CrossRef]

Cabello Martínez, María Josefa, and Irene Martínez Martín. 2017. Aportes teóricos de la perspectiva de género en la mejora de la educación de las niñas en África. Educación XXI: Revista de la Facultad de Educación 20: 163-81. [CrossRef]

Carvalho, Inês, Carlos Costa, Nina Lykke, and Anália Torres. 2019. Beyond the glass ceiling: Gendering tourism management. Annals of Tourism Research 75: 79-91. [CrossRef] 
Chan, Cecilia K. Y., Emily T. Y. Fong, Lilian Y. Y. Luk, and Robbie Ho. 2017. A review of literature on challenges in the development and implementation of generic competencies in higher education curriculum. International Journal of Educational Development 57: 1-10. [CrossRef]

Cohen, Scott, Paul Hanna, James Higham, Debbie Hopkins, and Caroline Orchiston. 2020. Gender discourses in academic mobility. Gender, Work \& Organisation 27: 149-65. [CrossRef]

Coleman, Jim. 2011. Study/Work Abroad and Employability. Shaping the Future. London: University Council of Modern Languages (UCML), Available online: http://www.ucml.ac.uk/sites/default/files/shapingthefuture/ 102/20jimcolemaninterresourcetemplate_0.pdf (accessed on 17 March 2020).

Crossman, Joanna Elizabeth, and Marilyn Clarke. 2010. International experience and graduate employability: Stakeholder perceptions on the connection. Higher Education 59: 599-613. [CrossRef]

Dashper, Katherine. 2019. Mentoring for gender equality: Supporting female leaders in the hospitality industry. International Journal of Hospitality Management.

Engel, Constanze. 2010. The impact of Erasmus mobility on the professional career: Empirical results of international studies on temporary student and teaching staff mobility. Belgeo Revue Belge de Géographie 4: 351-63. [CrossRef]

European Commission. 2017. Erasmus+ Enriching Lives, Opening Mind. Annual Report 2016. Available online: https:/ec.europa.eu/programmes/erasmus-plus/sites/erasmusplus2/files/annual-report-2016_en.pdf (accessed on 22 January 2020).

European Commission. 2018. Investing in People. Making Erasmus Even Better. Available online: https: //ec.europa.eu/commission/sites/beta-political/files/budget-may2018-erasmusplus_en.pdf (accessed on 22 January 2020).

European Commission. 2019. Erasmus+ Higher Education Impact Study. Available online: https://op.europa. eu/en/publication-detail/-/publication/94d97f5c-7ae2-11e9-9f05-01aa75ed71a1/language-en (accessed on 22 January 2020).

European Commission/EACEA/Eurydice. 2018. The European Higher Education Area in 2018: Bologna Process Implementation Report. Luxembourg: Publications Office of the European Union.

European Union. 2014. The ERASMUS Impact Study. Effects of Mobility on the Skills and Employability of Students and the Internationalisation of Higher Education Institutions. Luxembourg: Publications Office of the European Union.

Eurostat. 2019. Learning Mobility [Data File]. Available online: https:/ec.europa.eu/eurostat/data/database?node_ code-educ_uoe_mobs01 (accessed on 5 August 2019).

Fairclough, Tracey. 2018. Hospitality's gender pay gap. In Gender Issues in Tourism and Hospitality. Edited by Nigel Morgan, Ana-María Munar, Tracey Fairclough and Menna Jones. London: Greenwich University Public Lecture Series, vol. 14.

Festing, Marion, Lena Knappert, and Angela Kornau. 2015. Gender-specific preferences in global performance management: An empirical study of male and female managers in a multinational context. Human Resource Management 54: 55-79. [CrossRef]

Fontes, Margarida, Pedro Videira, and Teresa Calapez. 2013. The impact of long-term scientific mobility on the creation of persistent knowledge networks. Mobilities 8: 440-65. [CrossRef]

García-Blanco, Miriam, and Elsa Beatriz Cárdenas-Sempértegui. 2018. La inserción laboral en la Educación Superior. La perspectiva latinoamericana. [Job placement in Higher Education. The Latin American perspective]. Educación XX1 21: 323-47. [CrossRef]

Gök, Enes, Burak Aydın, and John Weidman. 2019. The impact of higher education on unemployed Turkish people's attitudes toward gender: A multilevel analysis. International Journal of Educational Development 66: 155-63. [CrossRef]

Guardià-Olmos, Joan, Maribel Peró-Cebollero, Mar Martínez-Ricart, Cristina Cañete-Massé, Jaume Turbany-Oset, and Vanesa Berlanga-Silvente. 2018. Employability of recent graduates. Opinions of Catalonian companies and institutions. Educación XX1 21: 155-77. [CrossRef]

Ferreira-Freire-Guimarães, Carla Regina, and Joaquim Ramos Silva. 2016. Pay gap by gender in the tourism industry of Brazil. Tourism Management 52: 440-50. [CrossRef] 
Humburg, M., R. Van der Velden, and A. Verhagen. 2013. The Employability of Higher Education Graduates: The Employers' Perspective. Maastricht: European Union Commission, Research Centre for Education and the Labour Market, Available online: https:/op.europa.eu/en/publication-detail/-/publication/ecbcc42d-349e4903-a844-9820680baa1a/language-en/format-PDF (accessed on 4 February 2020).

Jackson, Denise. 2016. Skill mastery and the formation of graduate identity in Bachelor graduates: Evidence from Australia. Studies in Higher Education 41: 1313-32. [CrossRef]

Jacobone, Vittoria, and Giuseppe Moro. 2015. Evaluating the impact of the Erasmus programme: Skills and European identity. Assessment \& Evaluation in Higher Education 40: 309-28.

Jöns, Heike. 2011. Transnational academic mobility and gender. Globalisation, Societies and Education 9: 183-209. [CrossRef]

Kumpikaitè, Vilmanté, and Kęstutis Duoba. 2013. Developing core competencies: Student mobility case. Procedia-Social and Behavioral Sciences 99: 828-34. [CrossRef]

Marsh, Sarah, and Terrence Bishop. 2014. Competency modeling in an undergraduate management degree program. Business Education \& Accreditation 6: 47-60.

Mei, Xiang Ying. 2019. Gaps in tourism education and workforce needs: Attracting and educating the right people. Current Issues in Tourism 22: 1400-4. [CrossRef]

Menon, Maria Eliophotou, Nicoletta Pashourtidou, Alexandros Polycarpour, and Panos Pashardes. 2012. Students' expectations about earnings and employment and the experience of recent university graduates: Evidence from Cyprus. International Journal of Educational Development 32: 805-13. [CrossRef]

Morgan, Nigel, and Annette Pritchard. 2019. Gender Matters in Hospitality (invited paper for 'luminaries' special issue of International Journal of Hospitality Management). International Journal of Hospitality Management 76: 38-44. [CrossRef]

Muñoz-Bullón, Fernando. 2009. The gap between male and female pay in the Spanish tourism industry. Tourism Management 30: 638-49. [CrossRef]

Nabi, Ghulam, and David Bagley. 1999. Graduates' perceptions of transferable personal skills and future career preparation in the UK. Education+ Training 41: 184-93. [CrossRef]

Nunnally, Jum, and Ira Bernstein. 1994. Psychometric Theory. New York: McGraw-Hill.

O'Leary, Simon. 2019. Gender and management implications from clearer signposting of employability attributes developed across graduate disciplines. Studies in Higher Education.

Paustian-Underdahl, Samantha, Lisa Slattery Walker, and David Woehr. 2014. Gender and perceptions of leadership effectiveness: A meta-analysis of contextual moderators. Journal of Applied Psychology 99: 1129-45. [CrossRef]

Perera, Srinath, Salomon Olusola Babatunde, Lei Zhou, John Pearson, and Damilola Ekundayo. 2017. Competency mapping framework for regulating professionally oriented degree programmes in higher education. Studies in Higher Education 42: 2316-42. [CrossRef]

Reuben, Ernesto, Paola Sapienza, and Luigi Zingales. 2014. How stereotypes impair women's careers in science. Proceedings of the National Academy of Sciences of the United States of America 111: 4403-8. [CrossRef]

Santero-Sanchez, Rosa, Mónica Segovia-Pérez, Belen Castro-Nuñez, Cristina Figueroa-Domecq, and Pilar Talón-Ballestero. 2015. Gender differences in the hospitality industry: A job quality index. Tourism Management 51: 234-46. [CrossRef]

Santos, Luís Delfim, and José Varejão. 2007. Employment, pay and discrimination in the tourism industry. Tourism Economics 13: 225-40. [CrossRef]

Segovia-Pérez, Mónica, Cristina Figueroa-Domecq, Laura Fuentes-Moraleda, and Ana Muñoz-Mazón. 2019. Incorporating a gender approach in the hospitality industry: Female executives' perceptions. International Journal of Hospitality Management 76: 184-93. [CrossRef]

Stamolampros, Panagiotis, Nikolaos Korfiatis, Konstantinos Chalvatzis, and Dimitrios Buhalis. 2019. Job satisfaction and employee turnover determinants in high contact services: Insights from Employees' Online reviews. Tourism Management 75: 130-47. [CrossRef]

Teichler, Ulrich. 1996. Student mobility in the framework of ERASMUS: Findings of an evaluation study. European Journal of Education 31: 153-79.

Tejada-Fernández, José, and Carmen Ruiz-Bueno. 2016. Evaluación de competencias profesionales en Educación Superior: Retos e implicaciones. [Evaluation of professional competences in Higher Education: Challenges and implications]. Educación XX1 19: 17-38. [CrossRef] 
Toncar, Mark, and Brian Cudmore. 2000. The overseas internship experience. Journal of Marketing Education 22: 54-63. [CrossRef]

Trooboff, Stevan, Michael Vande Berg, and Jack Rayman. 2008. Employer attitudes toward study abroad. Frontiers: The Interdisciplinary Journal of Study Abroad 15: 17-33. [CrossRef]

Turhan, Bugay. 2016. How students develop their competences through Erasmus mobility: Erasmus case in Hacettepe University. Educatia Plus 14: 96-103.

Won Kim, Sung, Cong Zhang, Hyeyon Chung, Yunjung Kim, and Su Yon Choi. 2020. Why do women value credentials? Perceptions of gender inequality and credentialism in South Korea. International Journal of Educational Development 73: 102158. [CrossRef]

(C) 2020 by the authors. Licensee MDPI, Basel, Switzerland. This article is an open access article distributed under the terms and conditions of the Creative Commons Attribution (CC BY) license (http://creativecommons.org/licenses/by/4.0/). 